\title{
Alteration in elemental and functional composition of heated peat humic acids
}

\author{
Natalya Chukhareva ${ }^{1, *}$, Mikhail Sartakov ${ }^{2}$, and Tatiana Korotchenko ${ }^{1}$ \\ ${ }^{1}$ Tomsk Polytechnic University, Institute of Natural Resources, 634050, Lenin Avenue, 30,Tomsk, \\ Russia \\ ${ }^{2}$ Yugra State University, Khanty-Mansiysk, Russia
}

\begin{abstract}
The article analyzes the effect of thermal modification of different-type peat on the alteration of elemental and functional composition of peat humic acids. Based on the data of IR-spectra and readings of electron paramagnetic resonance, structural alterations are identified. It is shown that the impact of peat characteristics on humic acids is preserved after thermal modification. It is revealed that the strongest alteration of humic acid composition and properties caused by peat heating are typical to humic acid samples extracted from the peat with low decomposition degree.
\end{abstract}

\section{Introduction}

Humic acids (HAs) are polydisperse components of soils, peat, and brown coal which are unique as they are characterized by a number of specific features. They are commonly used in the agricultural, environmental, and industrial sectors.

The latest studies have shown that HAs are heterpolycondensates carrying a great variety of functional groups which make macromolecules of HA different in composition, which, in its turn, contributes to the diversity of HA samples. This does not permit a holistic description of HA chemical structure. By now, it has been possible to propose some models and approximate formulas of HA molecule chemical structure [1].

In order to obtain more detailed description of HA chemical structure, it is proposed to use the methods of thermal modification, which makes it possible to reduce the effect of unstable peripheral structural groups on HA properties.

Thermal peat treatment at $250{ }^{\circ} \mathrm{C}$ in its decomposing gases is one of the abovementioned methods which is actively employed in the experiment to yield required humic acids from peat $[2,3]$.

The main objective of the study is to identify the effect of thermal modification of different-type peat on the structural alteration of HA.

\section{Research technique}

For the research, humic acids extracted from $0.25 \mathrm{~mm}$ fraction of air-dried terrestrial, transition, and fen peat samples heated in decomposing gases according to technique [3] have been chosen. The peat samples are characterized by low and medium decomposition degree $(\mathrm{R}=5 \ldots 45 \%)$, the data being provided in table 1 .

Table 1. Different-type peat characteristics.

\begin{tabular}{l|c|c|c|c|c|c|} 
Peat type & Group & R, & T, & Technical & Elemental analysis, $\%$ & Code HA \\
\hline
\end{tabular}

* Corresponding author: Natasha@tpu.ru 


\begin{tabular}{|c|c|c|c|c|c|c|c|c|c|c|}
\hline & & \multirow[t]{2}{*}{$\%$} & \multirow[t]{2}{*}{${ }^{\circ} \mathrm{C}$} & \multicolumn{2}{|c|}{$\begin{array}{c}\text { analysis *, } \\
\%\end{array}$} & \multicolumn{4}{|c|}{ daf** } & \\
\hline & & & & $\mathrm{W}^{\mathrm{a}}$ & $A^{d}$ & $\mathrm{C}$ & $\mathrm{H}$ & $\mathrm{O}+\mathrm{S}$ & $\mathrm{N}$ & \\
\hline \multicolumn{11}{|c|}{ terrestrial peat } \\
\hline \multirow{2}{*}{ Sphagnum } & \multirow{2}{*}{$\begin{array}{l}\text { moss } \\
\text { peat }\end{array}$} & \multirow{2}{*}{5} & - & 8.4 & 1.9 & 52.1 & 6.3 & 40.7 & 0.9 & $\mathrm{HA}(1 \mathrm{Ph})$ \\
\hline & & & 250 & 1.2 & 2.1 & 55.1 & 5.5 & 37.9 & 1.5 & $\mathrm{HA}\left(1 \mathrm{Ph}_{250}\right)$ \\
\hline \multirow[t]{2}{*}{ Fuskum-peat } & \multirow{2}{*}{$\begin{array}{l}\text { moss } \\
\text { peat }\end{array}$} & \multirow{2}{*}{10} & - & 6.2 & 1.3 & 52.2 & 5.4 & 41.7 & 0.7 & $\mathrm{HA}(3 \mathrm{Ph})$ \\
\hline & & & 250 & 1.3 & 2.4 & 60.3 & 5.0 & 33.0 & 1.7 & $\mathrm{HA}\left(3 \mathrm{Ph}_{250}\right)$ \\
\hline \multirow{2}{*}{ Megallanicum } & \multirow{2}{*}{$\begin{array}{l}\text { moss } \\
\text { peat }\end{array}$} & \multirow{2}{*}{10} & - & 7.8 & 2.9 & 54.3 & 4.2 & 39.8 & 1.7 & $\mathrm{HA}(2 \mathrm{Ph})$ \\
\hline & & & 250 & 1.5 & 5.1 & 59.9 & 4.0 & 33.8 & 2.3 & $\mathrm{HA}\left(2 \mathrm{Ph}_{250}\right)$ \\
\hline \multirow{2}{*}{$\begin{array}{l}\text { Cottongrass- } \\
\text { sphagnum }\end{array}$} & \multirow{2}{*}{$\begin{array}{l}\text { grass- } \\
\text { moss }\end{array}$} & \multirow{2}{*}{25} & - & 8.2 & 1.9 & 55.8 & 6.0 & 36.7 & 1.5 & $\mathrm{HA}(4 \mathrm{Ph})$ \\
\hline & & & 250 & 0.7 & 2.5 & 58.7 & 5.8 & 33.2 & 2.3 & $\mathrm{HA}\left(4 \mathrm{Ph}_{250}\right)$ \\
\hline \multirow{2}{*}{$\begin{array}{l}\text { Cottongrass- } \\
\text { sphagnum }\end{array}$} & \multirow{2}{*}{ grass } & \multirow{2}{*}{35} & - & 6.6 & 2.3 & 57.1 & 6.1 & 35.5 & 1.3 & $\mathrm{HA}(5 \mathrm{Ph})$ \\
\hline & & & 250 & 1.8 & 3.5 & 62.2 & 6.0 & 29.9 & 1.9 & $\mathrm{HA}\left(5 \mathrm{Ph}_{250}\right)$ \\
\hline \multirow{2}{*}{ Scheuchzeria } & \multirow{2}{*}{ grass } & \multirow{2}{*}{40} & - & 11.1 & 7.8 & 57.9 & 5.9 & 33.7 & 2.5 & $\mathrm{HA}(6 \mathrm{Ph})$ \\
\hline & & & 250 & 0.8 & 13.7 & 59.8 & 5.7 & 31.4 & 3.1 & $\mathrm{HA}\left(6 \mathrm{Ph}_{250}\right)$ \\
\hline \multicolumn{11}{|c|}{ transition peat } \\
\hline \multirow{2}{*}{ Scheuchzeria } & \multirow{2}{*}{ grass } & \multirow{2}{*}{20} & - & 7.4 & 8.4 & 53.8 & 6.1 & 37.2 & 2.9 & $\mathrm{HA}(1 \mathrm{Pm})$ \\
\hline & & & 250 & 1.0 & 11.7 & 66.4 & 5.3 & 24.0 & 4.3 & $\mathrm{HA}\left(1 \mathrm{Pm}_{250}\right)$ \\
\hline \multirow{2}{*}{$\begin{array}{l}\text { Sedge- } \\
\text { sphagnum }\end{array}$} & \multirow{2}{*}{$\begin{array}{l}\text { grass- } \\
\text { moss }\end{array}$} & 25 & - & 6.7 & 6.6 & 55.9 & 5.2 & 36.9 & 2.0 & $\mathrm{HA}(2 \mathrm{Pm})$ \\
\hline & & 25 & 250 & 1.3 & 8.2 & 58.1 & 4.9 & 33.3 & 3.7 & $\mathrm{HA}\left(2 \mathrm{Pm}_{250}\right)$ \\
\hline Sedge- & grass- & & - & 7.2 & 4.4 & 56.9 & 5.9 & 35.1 & 2.1 & $\mathrm{HA}(3 \mathrm{Pm})$ \\
\hline sphagnum & moss & 35 & 250 & 1.2 & 5.2 & 59.7 & 5.7 & 31.9 & 2.7 & $\mathrm{HA}\left(3 \mathrm{Pm}_{250}\right)$ \\
\hline & & & & & peat & & & & & \\
\hline Sedge-hypnum & grass- & 25 & - & 8.2 & 8.9 & 43.4 & 5.6 & 45.1 & 5.9 & $\mathrm{HA}(1 \mathrm{Pl})$ \\
\hline & moss & 25 & 250 & 0.5 & 18.2 & 54.6 & 5.3 & 33.8 & 6.3 & $\mathrm{HA}\left(1 \mathrm{Pl}_{250}\right)$ \\
\hline Woody-sedge & woodv & 30 & - & 7.1 & 10.3 & 56.0 & 6.0 & 34.9 & 3.1 & $\mathrm{HA}(2 \mathrm{Pl})$ \\
\hline peat & woody & 30 & 250 & 0.9 & 10.7 & 58.1 & 5.6 & 32.8 & 3.5 & $\mathrm{HA}\left(2 \mathrm{Pl}_{250}\right)$ \\
\hline & & & - & 7.6 & 6.1 & 52.8 & 6.3 & 36.4 & 4.5 & $\mathrm{HA}(3 \mathrm{Pl})$ \\
\hline Sedge peat & grass & 35 & 250 & 1.2 & 6.9 & 58.1 & 5.8 & 31.5 & 4.6 & $\mathrm{HA}\left(3 \mathrm{Pl}_{250}\right)$ \\
\hline
\end{tabular}

* $\mathrm{W}$ a - moisture of analysis sample, Ad - ash content on air-dried basis, Vodaf - yield of volatile matter on dry ash-free basis, ${ }^{* *}$ daf - on air-dried and ash free basis; $\mathrm{O}+\mathrm{S}$ is obtained by difference, with $\mathrm{S}$ content being not more than $2 \%$

The humic acids (НА и $\mathrm{HA}_{250}$ ) were extracted in accordance with the following technique [4]: 1) bitumen was extracted by the use of benzene; 2) water-soluble and easyhydrolysable substances were extracted from bitumen-free peat samples (extraction of 4\%$\mathrm{HCl}$ ); 3) humic acids were extracted from peat samples free from bitumen, water-soluble and easy-hydrolysable substances (treatment of $0,1 \mathrm{H}$ by solution $\mathrm{NaOH}$ and further precipitation of $\mathrm{HA}$ by $10 \%-\mathrm{HC} \ell$ ).

The functional acid groups (carboxy group and phenolic hydroxyl) in macromolecule $\mathrm{HA}$ and $\mathrm{HA}_{250}$ were identified by defining their total content by means of Barium oxydatum, followed by identification of $\mathrm{COOH}$ group by Calcium acetate, and $\mathrm{OH}$ group identification by the difference $(\mathrm{OH}+\mathrm{COOH})-(\mathrm{COOH})$ according to technique [4].

All samples $\mathrm{HA}$ and $\mathrm{HA}_{250}$ were examined for $\mathrm{C}, \mathrm{H}, \mathrm{N}, \mathrm{O}+\mathrm{S}$ content (hereinafter oxygen) by means of automatic elemental analyzer EURO EA3000 in accordance with technique [5]. The discordance between the data met the following conditions: $n \geq 3$, when $\mathrm{P}=0.95$.

The conditions of the experiment aimed at identifying paramagnetic properties of HA and $\mathrm{HA}_{250}$ (readings of electron paramagnetic resonance) were as follows: electron 
paramagnetic resonance (EPR) -spectrometer Bruker ELEXSYS E-540 (Novosibirsk Institute of Organic Chemistry of the Siberian Branch of Russian Academy of Science); Xband at $10 \mathrm{GHz}$; g-factor was identified by inside frequency meter spectra, with gauge correction to g-factor DPPH; measurements were carried out on a Bruker ELEXSYS E-540 in EPR ampoules, MW power $=10 \mathrm{~dB}$. The number of electron spins was calculated in accordance with the method developed by «Bruker» - Absolute spins [7]. The accuracy of spin number determination was $\pm 15 \%$.

The optical properties of HA and $\mathrm{HA}_{250}$ were studied using the Nicolet iS10 FT-IR spectrometer, Termo Fisher Scientific. The IR spectrometer was fitted with an add-on device containing $\mathrm{ZnSe}$ crystal for frustrated internal reflectance. The experiment parameters were as follows: resolution $-4 \mathrm{~cm}^{-1}$, the number of sample scans and comparison spectrum - 128, scan range was from 4000 up to $650 \mathrm{~cm}^{-1}$. The spectra were registered and processed using Omnic 8.3 [6].

\section{Results and discussion}

The obtained data on elemental and functional composition of $\mathrm{HA}$ and $\mathrm{HA}_{250}$ are given in table 2.

Table 2. The characteristics of HA elemental and functional composition.

\begin{tabular}{|c|c|c|c|c|c|c|c|c|}
\hline \multirow[t]{2}{*}{ Code HA } & \multirow[t]{2}{*}{$\mathrm{W}^{\mathrm{a}}, \%$} & \multirow[t]{2}{*}{$\mathrm{A}^{\mathrm{d}}, \%$} & \multicolumn{4}{|c|}{ Elemental composition, $\%$ daf } & \multicolumn{2}{|c|}{$\begin{array}{l}\text { Functional com } \\
\text { position, mg-eq/g }\end{array}$} \\
\hline & & & $\mathrm{C}$ & $\mathrm{H}$ & $\mathrm{O}$ & $\mathrm{N}$ & $\mathrm{COOH}$ & $\mathrm{OH}$ \\
\hline \multicolumn{9}{|c|}{ humic acids of terrestrial peat, decomposition degree 5-10\% } \\
\hline $\mathrm{HA}(1 \mathrm{Ph}) /$ & $2.1 /$ & $0.1 /$ & $56.2 /$ & $6.1 /$ & $35.8 /$ & $1.9 /$ & $3.5 /$ & $4.0 /$ \\
\hline $\mathrm{HA}\left(1 \mathrm{Ph}_{250}\right)$ & 3.1 & 0.1 & 62.0 & 4.7 & 31.5 & 2.1 & 3.9 & 3.9 \\
\hline $\mathrm{HA}(2 \mathrm{Ph}) /$ & $2.1 /$ & $0.1 /$ & $57.8 /$ & $5.9 /$ & $34.7 /$ & $1.6 /$ & $3.6 /$ & $3.8 /$ \\
\hline $\mathrm{HA}\left(2 \mathrm{Ph}_{250}\right)$ & 3.7 & 0.4 & 64.7 & 5.4 & 28.1 & 1.8 & 4.1 & 3.8 \\
\hline $\mathrm{HA}(3 \mathrm{Ph}) /$ & $5.5 /$ & $0.5 /$ & $58.4 /$ & $5.7 /$ & 34.21 & $1.7 /$ & $3.3 /$ & $3.5 /$ \\
\hline $\mathrm{HA}\left(3 \mathrm{Ph}_{250}\right)$ & 4.1 & 0.3 & 62.6 & 5.1 & 30.3 & 2.0 & 3.8 & 3.5 \\
\hline \multicolumn{9}{|c|}{ alteration of elemental composition and functional groups in HA, \% respectively } \\
\hline & & & $+\Delta \mathrm{C}$ & $-\Delta \mathrm{H}$ & $-\Delta \mathrm{O}$ & $+\Delta \mathrm{N}$ & $+\Delta \mathrm{COOH}$ & $-\Delta \mathrm{OH}$ \\
\hline $\mathrm{HA}\left(1 \mathrm{Ph}_{250}\right) / \mathrm{H}$ & $(1 \mathrm{Ph})$ & & 10.3 & 22.9 & 12.0 & 10.5 & 11.4 & 2.5 \\
\hline $\mathrm{HA}\left(2 \mathrm{Ph}_{250}\right) / \mathrm{H}$ & $2 \mathrm{Ph})$ & & 12.0 & 8.5 & 19.0 & 12.5 & 13.9 & - \\
\hline $\mathrm{HA}\left(3 \mathrm{Ph}_{250}\right) / \mathrm{H}$ & $(3 \mathrm{Ph})$ & & 7.2 & 10.5 & 11.4 & 17.6 & 15.2 & - \\
\hline \multicolumn{9}{|c|}{ humic acids of terrestrial peat, decomposition degree $25-40 \%$} \\
\hline $\mathrm{HA}(4 \mathrm{Ph}) /$ & $5.7 /$ & $0.8 /$ & $60.0 /$ & $5.2 /$ & $32.2 /$ & $2.6 /$ & $3.4 /$ & $3.1 /$ \\
\hline $\mathrm{HA}\left(4 \mathrm{Ph}_{250}\right)$ & 3.1 & 0.2 & 60.7 & 4.9 & 31.7 & 2.7 & 3.6 & 3.1 \\
\hline $\mathrm{HA}(5 \mathrm{Ph}) /$ & $9.2 /$ & $0.7 /$ & $58.9 /$ & $5.3 /$ & $33.7 /$ & $2.1 /$ & $3.5 /$ & $3.2 /$ \\
\hline $\mathrm{HA}\left(5 \mathrm{Ph}_{250}\right)$ & 3.6 & 0.1 & 60.7 & 4.9 & 32.2 & 2.2 & 3.7 & 3.2 \\
\hline $\mathrm{HA}(6 \mathrm{Ph}) /$ & $6.4 /$ & $0.1 /$ & $61.5 /$ & $5.3 /$ & $30.8 /$ & $2.4 /$ & $3.7 /$ & $3.3 /$ \\
\hline $\mathrm{HA}\left(6 \mathrm{Ph}_{250}\right)$ & 8.2 & 0.2 & 62.0 & 4.9 & 30.3 & 2.8 & 3.9 & 3.1 \\
\hline \multicolumn{9}{|c|}{ alteration of elemental composition and functional groups in HA, \% respectively } \\
\hline & & & $+\Delta \mathrm{C}$ & $-\Delta \mathrm{H}$ & $-\Delta \mathrm{O}$ & $+\Delta \mathrm{N}$ & $+\Delta \mathrm{COOH}$ & $-\Delta \mathrm{OH}$ \\
\hline $\mathrm{HA}\left(4 \mathrm{Ph}_{250}\right) / \mathrm{H}$ & $(4 \mathrm{Ph})$ & & 1.2 & 5.8 & 1.6 & 3.8 & 5.9 & - \\
\hline $\mathrm{HA}\left(5 \mathrm{Ph}_{250}\right) / \mathrm{H}$ & & & 3.1 & 7.5 & 4.5 & 4.8 & 5.7 & - \\
\hline $\mathrm{HA}\left(6 \mathrm{Ph}_{250}\right) / \mathrm{H}$ & $(6 \mathrm{Ph})$ & & 0.8 & 7.5 & 1.6 & 16.7 & 5.4 & 6.1 \\
\hline \multicolumn{9}{|c|}{ humic acids of transition peat, decomposition degree $20-35 \%$} \\
\hline $\mathrm{HA}(1 \mathrm{Pm}) /$ & $8.1 /$ & $0.6 /$ & $60.0 /$ & $5.3 /$ & $31.7 /$ & $3.0 /$ & $3.1 /$ & $3.3 /$ \\
\hline $\mathrm{HA}\left(1 \mathrm{Pm}_{250}\right)$ & 4.9 & 0.1 & 62.0 & 4.8 & 30.0 & 3.2 & 3.3 & 3.1 \\
\hline $\mathrm{HA}(2 \mathrm{Pm}) /$ & $5.0 /$ & $0.8 /$ & $58.8 /$ & $5.1 /$ & $32.7 /$ & $3.4 /$ & $2.7 /$ & $3.6 /$ \\
\hline $\mathrm{HA}\left(2 \mathrm{Pm}_{250}\right)$ & 5.1 & 0.4 & 61.4 & 4.5 & 30.6 & 3.5 & 3.0 & 3.4 \\
\hline $\mathrm{HA}(3 \mathrm{Pm}) /$ & $6.9 /$ & $0.1 /$ & $60.1 /$ & $4.9 /$ & $32.0 /$ & $3.0 /$ & $2.1 /$ & $4.1 /$ \\
\hline $\mathrm{HA}\left(3 \mathrm{Pm}_{250}\right)$ & 3.5 & 0.2 & 61.5 & 4.2 & 31.1 & 3.2 & 2.4 & 4.1 \\
\hline
\end{tabular}




\begin{tabular}{|c|c|c|c|c|c|c|c|c|}
\hline \multicolumn{9}{|c|}{ alteration of elemental composition and functional groups in HA, \% respectively } \\
\hline & & & $+\Delta \mathrm{C}$ & $-\Delta \mathrm{H}$ & $-\Delta \mathrm{O}$ & $+\Delta \mathrm{N}$ & $+\triangle \mathrm{COOH}$ & $-\Delta \mathrm{OH}$ \\
\hline \multicolumn{3}{|c|}{$\mathrm{HA}\left(1 \mathrm{Pm}_{250}\right) / \mathrm{HA}(1 \mathrm{Pm})$} & 3.3 & 9.4 & 5.4 & 6.7 & 6.5 & 6.1 \\
\hline \multicolumn{3}{|c|}{$\mathrm{HA}\left(2 \mathrm{Pm}_{250}\right) / \mathrm{HA}(2 \mathrm{Pm})$} & 4.4 & 11.8 & 6.4 & 2.9 & 11.1 & 5.6 \\
\hline \multicolumn{3}{|c|}{$\mathrm{HA}\left(3 \mathrm{Pm}_{250}\right) / \mathrm{HA}(3 \mathrm{Pm})$} & 2.3 & 14.3 & 2.8 & 6.7 & 14.3 & - \\
\hline \multicolumn{9}{|c|}{ humic acids of fen peat, decomposition degree $25-35 \%$} \\
\hline $\mathrm{HA}(1 \mathrm{Pl}) /$ & $8.1 /$ & $1.1 /$ & 59.8 & $4.8 /$ & $32.6 /$ & \multirow{2}{*}{$2.8 / 3.2$} & $3.3 /$ & $3.2 /$ \\
\hline $\mathrm{HA}\left(1 \mathrm{Pl}_{250}\right)$ & 4.1 & 0.2 & 62.0 & 4.3 & 30.5 & & 3.5 & 3.1 \\
\hline $\mathrm{HA}(2 \mathrm{Pl}) /$ & $9.8 /$ & $0.3 /$ & 61.3 & $5.0 /$ & $30.1 /$ & \multirow{2}{*}{ 3.6/3.6 } & $3.1 /$ & $3.3 /$ \\
\hline $\mathrm{HA}\left(2 \mathrm{Pl}_{250}\right)$ & 3.4 & 0.4 & 63.7 & 4.6 & 28.1 & & 3.3 & 3.4 \\
\hline $\mathrm{HA}(3 \mathrm{Pl}) /$ & $9.4 /$ & $0.4 /$ & $61.2 /$ & $4.7 /$ & 30.9 & \multirow{2}{*}{$3.2 / 3.4$} & $2.9 /$ & $3.4 /$ \\
\hline $\mathrm{HA}\left(3 \mathrm{Pl}_{250}\right)$ & 5.1 & 0.1 & 63.6 & 4.8 & 28.2 & & 3.1 & 3.4 \\
\hline \multicolumn{9}{|c|}{ alteration of elemental composition and functional groups in HA, $\%$ respectively } \\
\hline & & & $+\Delta \mathrm{C}$ & $-\Delta \mathrm{H}$ & $-\Delta \mathrm{O}$ & $+\Delta \mathrm{N}$ & $+\Delta \mathrm{COOH}$ & $-\Delta \mathrm{OH}$ \\
\hline \multicolumn{3}{|c|}{$\mathrm{HA}\left(1 \mathrm{Pl}_{250}\right) / \mathrm{HA}(1 \mathrm{Pl})$} & 3.7 & 10.4 & 6.4 & 14.3 & 6.1 & 3.1 \\
\hline \multicolumn{3}{|c|}{$\mathrm{HA}\left(2 \mathrm{Pl}_{250}\right) / \mathrm{HA}(2 \mathrm{Pl})$} & 3.9 & 8.0 & 6.6 & - & 6.5 & 3.0 \\
\hline \multicolumn{3}{|c|}{$\mathrm{HA}\left(3 \mathrm{Pl}_{250}\right) / \mathrm{HA}(3 \mathrm{Pl})$} & 3.9 & 2.1 & 8.7 & 6.3 & 6.9 & - \\
\hline
\end{tabular}

The data suggest that the average content of $\mathrm{C}, \mathrm{H}, \mathrm{O}, \mathrm{N}$ elements is within the range specific to peat humic acids $[8,9]$. Based on peat decomposition degree, certain regularities in elemental composition of HA samples were identified. High values of C $(58.8 \div 61.5 \%$ daf) and $\mathrm{N}(2.1 \div 3.6)$ are characteristic feature of terrestrial, transition, and fen peat HAs with the average decomposition degree $(\mathrm{R}=20-40 \%)$. High values of $\mathrm{H}(5.7 \div 6.1 \%$ daf $)$ and $\mathrm{O}(34.2 \div 35.8 \%$ daf) are characteristic feature of terrestrial peat HAs with low decomposition degree $(\mathrm{R}=5-10 \%)$.

The preliminary heat treatment of peat $\mathrm{HA}_{250}$ led to carbon increase, oxygen and hydrogen decrease. The results demonstrated minimum changes in nitrogen content as compared to alteration degree of other elements.

The above-mentioned regularities are not preserved after peat heat treatment. At the same time, when comparing the relative alteration of element content $(+\Delta \mathrm{C},-\Delta \mathrm{H},-\Delta \mathrm{O}$, $+\Delta \mathrm{N})$ in samples $\mathrm{HA}_{250}$, the effect of peat $\mathrm{R}$ finds its maximum.

The maximum relative alterations of element content are obtained for $\mathrm{HA}\left(1 \mathrm{Ph}_{250}\right)$, $\mathrm{HA}\left(2 \mathrm{Ph}_{250}\right), \mathrm{HA}\left(2 \mathrm{Ph}_{250}\right)$ of thermally treated terrestrial peat with low decomposition degree $\mathrm{R}(5-10 \%)$. They are as follows: $+\Delta \mathrm{C}=7,2 \div 12,0 \%$ respectively; $-\Delta \mathrm{H}=8,5 \div 22,9 \%$ respectively; $-\Delta \mathrm{O}=11,4 \div 19,0 \% ;+\Delta \mathrm{N}=10,5 \div 17,6 \%$ respectively.

The rest samples $\mathrm{HA}\left(4 \mathrm{Ph}_{250}\right), \mathrm{HA}\left(5 \mathrm{Ph}_{250}\right), \mathrm{HA}\left(6 \mathrm{Ph}_{250}\right), \mathrm{HA}\left(1 \mathrm{Pm}_{250}\right), \mathrm{HA}\left(2 \mathrm{Pm}_{250}\right)$, $\mathrm{HA}\left(3 \mathrm{Pm}_{250}\right), \mathrm{HA}\left(1 \mathrm{Pl}_{250}\right), \mathrm{HA}\left(2 \mathrm{Pl}_{250}\right), \mathrm{HA}\left(3 \mathrm{Pl}_{250}\right)$ are characterized by lower values: $+\Delta \mathrm{C}=$ $0,8 \div 4,4 \%$ respectively; $-\Delta \mathrm{H}=2,1 \div 14,3 \%$ respectively; $-\Delta \mathrm{O}=1,6 \div 8,7 \% ;+\Delta \mathrm{N}=2,9 \div 14,3$ $\%$ respectively.

Thus, it has been stated that the higher peat $\mathrm{R}$ is, the lower is the effect of peat heat treatment on relative alterations of $\mathrm{C}, \mathrm{H}, \mathrm{O} \mathrm{N}$ content in the organic macromolecule of humic acids.

The data on functional composition indicate that the number of oxygen-containing functional groups is within the range typical for peat humic acids in all samples HA and $\mathrm{HA}_{250}[10]$.

Peat heat treatment leads to the increase in $\mathrm{COOH}$-group content in modified humic acids. The number of hydroxyl $\mathrm{OH}$-groups decreases or remains unchanged (table 2).

The increase in carboxyl groups in $\mathrm{HA}_{250}$ composition can stipulate their reaction capacity [11]. At the same time, it is necessary to consider not only the number of functional groups, but also their differentiation based on acidity level (difference in molecular environment within the macromolecule). 
When comparing infrared spectra of $\mathrm{HA}$ and $\mathrm{HA}_{250}$, it has been revealed that all $\mathrm{HA}$ samples are characterized by uniformity of functional groups.

The absorption bands that are typical for HAs are observed in infrared spectra of HA and $\mathrm{HA}_{250}$ in the $\mathrm{OH}$-group stretch $\left(3400 \mathrm{~cm}^{-1}\right)$. The bands are linked by hydrogen bonds. The absorption bands are also observed in $\mathrm{CH}_{2}$-group stretch, methyl $\mathrm{CH}_{3}$-group (2920 $\mathrm{cm}^{-} 1$ and $\left.2850 \mathrm{~cm}^{-1}\right)$, carboxyl $\mathrm{C}=\mathrm{O}$-group $\left(1725-1700 \mathrm{~cm}^{-1}\right), \mathrm{C}=\mathrm{C}$ polycoupled aromatic systems and monoaromatic structures $\left(1620-1600 \mathrm{~cm}^{-1}\right.$ and $\left.1520-1500 \mathrm{~cm}^{-1}\right)$. Faint absorption bands are defined in vibration bending of $\mathrm{C}-\mathrm{CH}_{3}$-groups $\left(1390-1370 \mathrm{~cm}^{-1}\right)$ and $\mathrm{C}-\mathrm{O}$ stretch of acids and phenols $\left(1250-1200 \mathrm{~cm}^{-1}\right)$. The band $1100-1000 \mathrm{~cm}^{-1}$ corresponds to $\mathrm{C}-\mathrm{O}$-group stretch of alcohols (figure 1).
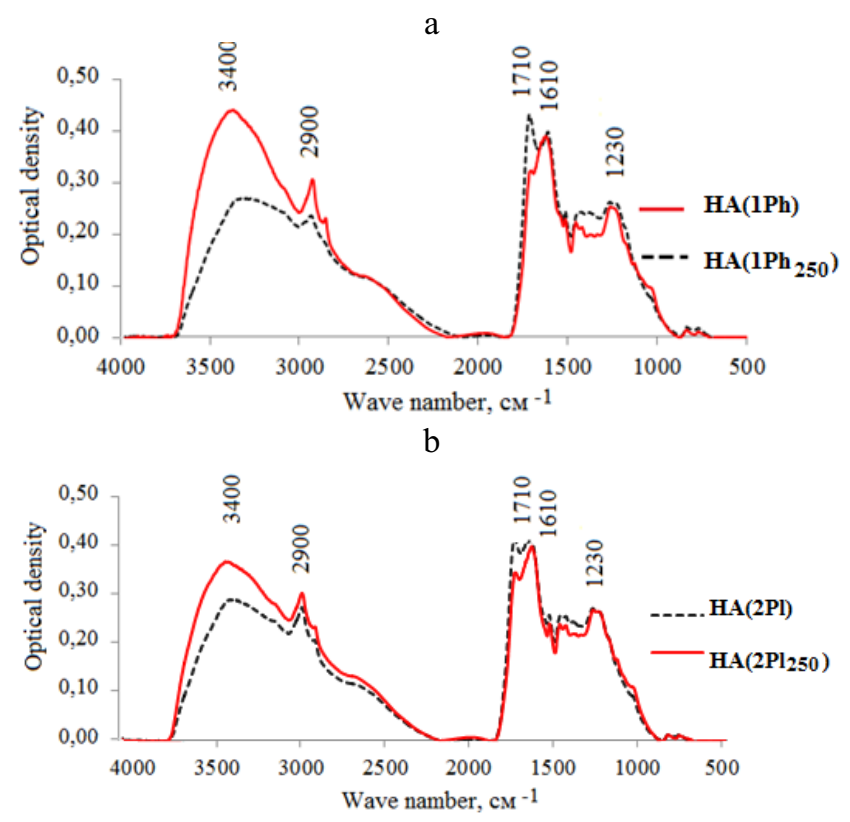

Fig. 1. IR-spectra of humic acids in air-dried and heat treated terrestrial peat, $R=5 \%$ (a) and fen woody peat, $\mathrm{R}=30 \%(\mathrm{~b})$.

Peat heat treatment in $\mathrm{HA}_{250}$ IR-spectra decreases the intensity of $\mathrm{OH}$-groups and $\mathrm{C}-\mathrm{H}$ groups stretch at $3400 \mathrm{~cm}^{-1}$ and $2920 \mathrm{~cm}^{-1}$, which, in its turn, indicates the presence of dehydration reactions at low-temperature thermal decomposition at the stage of peat heating.

The intensity alteration of absorption bands of $\mathrm{C}=\mathrm{O}$-groups at $1725-1700 \mathrm{~cm}^{-1}$ and $\mathrm{C}-$ O-groups of acids and phenols at $1250-1200 \mathrm{~cm}^{-1}$ has been determined. This can be caused by interaction of HA thermal decomposition products (alcohol ester, alcohol oxide, and ketone) with water forming new carboxyl groups $[10,11]$. Besides, carboxyl groups can also be formed due to hydrolyze ester bonds that bind other peat components. This fact has been proved by analyzing kinetic parameters of peat components thermal decomposition in [12].

To obtain the data on HA structure, characterized by hetero-polycondensates of irregular composition (methyl-bearing hydroxycarboxylic acids with fused rings including $\mathrm{O}, \mathrm{N}, \mathrm{S}$-bearing heterocycles and side chains, as well as other functional groups in nucleus and peripheral parts $[1,4,10])$, atomic ratios $\mathrm{H}: \mathrm{C}$ and $\mathrm{O}: \mathrm{C}$ have been calculated on the basis of elemental composition. 
In order to obtain the characteristics of $\mathrm{HA}$ and $\mathrm{HA}_{250}$ aromaticity using the VanKrevelen's equation [11], aromaticity index (A) and the number of aromatic rings (B) for the statistical carbon nucleus of a molecule have been defined.

The obtained number of spins in the sample $s=1 / 2$ was recalculated for $1 \mathrm{~g}$ of the sample size $\left(\mathrm{I} \cdot 10^{17}\right)$. The results are given in table 3 .

Table 3. Humic acid aromaticity.

\begin{tabular}{|c|c|c|c|c|c|c|}
\hline \multirow[t]{2}{*}{ HA code } & \multicolumn{2}{|c|}{$\begin{array}{l}\text { Atomic } \\
\text { relations }\end{array}$} & \multicolumn{2}{|c|}{$\begin{array}{l}\text { the Van-Krevelen's } \\
\text { equation parameters }\end{array}$} & \multicolumn{2}{|c|}{$\begin{array}{c}\text { Readings of electron } \\
\text { paramagnetic resonance }\end{array}$} \\
\hline & $H: C$ & $O: C$ & $A$ & $B$ & $\begin{array}{l}\text { Spin for } g, \\
I \cdot 10^{17}\end{array}$ & $g$-factor \\
\hline \multicolumn{7}{|c|}{ humic acids of terrestrial peat, decomposition degree 5-10 \% } \\
\hline $\mathrm{HA}(1 \mathrm{Ph}) / \mathrm{HA}\left(1 \mathrm{Ph}_{250}\right)$ & $\begin{array}{l}1.25 / \\
1.13 \\
\end{array}$ & $\begin{array}{c}0.48 / \\
0.38 \\
\end{array}$ & $\begin{array}{l}3.11 / \\
4.40\end{array}$ & $\begin{array}{l}0.48 / \\
1.33 \\
\end{array}$ & $\begin{array}{c}0.97 / \\
1.80 \\
\end{array}$ & $2.0039 / 2.0034$ \\
\hline $\mathrm{HA}(2 \mathrm{Ph}) / \mathrm{HA}\left(2 \mathrm{Ph}_{250}\right)$ & $\begin{array}{l}1.21 / \\
0.99 \\
\end{array}$ & $\begin{array}{l}0.45 / \\
0.33 \\
\end{array}$ & $\begin{array}{l}3.30 / \\
4.02 \\
\end{array}$ & $\begin{array}{l}0.57 / \\
1.02 \\
\end{array}$ & $\begin{array}{l}1.78 / \\
1.81 \\
\end{array}$ & $2.0034 / 2.0034$ \\
\hline $\mathrm{HA}(3 \mathrm{Ph}) / \mathrm{HA}\left(3 \mathrm{Ph}_{250}\right)$ & $\begin{array}{l}0.17 / \\
1.14 \\
\end{array}$ & $\begin{array}{l}0.44 / \\
0.36 \\
\end{array}$ & $\begin{array}{l}3.42 / \\
4.16\end{array}$ & $\begin{array}{l}0.63 / \\
1.12 \\
\end{array}$ & $\begin{array}{l}1.85 / \\
3.09\end{array}$ & $2.0030 / 2.0038$ \\
\hline \multicolumn{7}{|c|}{ humic acids of terrestrial peat, decomposition degree $25-40 \%$} \\
\hline $\mathrm{HA}(4 \mathrm{Ph}) / \mathrm{HA}\left(4 \mathrm{Ph}_{250}\right)$ & $\begin{array}{l}1.04 / \\
0.97 \\
\end{array}$ & $\begin{array}{l}0.40 / \\
0.39 \\
\end{array}$ & $\begin{array}{l}3.86 / \\
4.14\end{array}$ & $\begin{array}{c}0.90 / \\
1.11 \\
\end{array}$ & $\begin{array}{l}0.0 / \\
1.77\end{array}$ & $2.0038 / 2.0038$ \\
\hline $\mathrm{HA}(5 \mathrm{Ph}) / \mathrm{HA}\left(5 \mathrm{Ph}_{250}\right)$ & $\begin{array}{l}1.07 / \\
0.96 \\
\end{array}$ & $\begin{array}{l}0.43 / \\
0.40\end{array}$ & $\begin{array}{l}3.73 / \\
4.17 \\
\end{array}$ & $\begin{array}{l}0.81 / \\
1.13 \\
\end{array}$ & $\begin{array}{l}2.02 / \\
2.29 \\
\end{array}$ & $2.0031 / 2.0035$ \\
\hline $\mathrm{HA}(6 \mathrm{Ph}) / \mathrm{HA}\left(6 \mathrm{Ph}_{250}\right)$ & $\begin{array}{l}1.02 / \\
0.94 \\
\end{array}$ & $\begin{array}{l}0.38 / \\
0.37 \\
\end{array}$ & $\begin{array}{l}3.91 / \\
4.28\end{array}$ & $\begin{array}{l}0.94 / \\
1.22 \\
\end{array}$ & $\begin{array}{l}0.92 / \\
3.57 \\
\end{array}$ & $2.0038 / 2.0032$ \\
\hline \multicolumn{7}{|c|}{ humic acids of transition peat, decomposition degree $20-35 \%$} \\
\hline $\mathrm{HA}(1 \mathrm{Pm}) / \mathrm{HA}\left(1 \mathrm{Pm}_{250}\right)$ & $\begin{array}{l}1.05 / \\
0.92 \\
\end{array}$ & $\begin{array}{l}0.40 / \\
0.36 \\
\end{array}$ & $\begin{array}{l}3.79 / \\
4.34 \\
\end{array}$ & $\begin{array}{l}0.85 / \\
1.28\end{array}$ & $\begin{array}{l}1.82 / \\
2.61 \\
\end{array}$ & $2.0036 / 2.0034$ \\
\hline $\mathrm{HA}(2 \mathrm{Pm}) / \mathrm{HA}\left(2 \mathrm{Pm}_{250}\right)$ & $\begin{array}{l}1.03 / \\
0.88 \\
\end{array}$ & $\begin{array}{l}0.42 / \\
0.37 \\
\end{array}$ & $\begin{array}{l}3.89 / \\
4.56 \\
\end{array}$ & $\begin{array}{l}0.92 / \\
1.48 \\
\end{array}$ & $\begin{array}{l}1.42 / \\
1.80\end{array}$ & $2.0035 / 2.0037$ \\
\hline $\mathrm{HA}(3 \mathrm{Pm}) / \mathrm{HA}\left(3 \mathrm{Pm}_{250}\right)$ & $\begin{array}{l}0.96 / \\
0.82\end{array}$ & $\begin{array}{l}0.40 / \\
0.38\end{array}$ & $\begin{array}{l}4.15 / \\
4.89\end{array}$ & $\begin{array}{l}1.12 / \\
1.82\end{array}$ & $\begin{array}{l}1.17 / \\
1.98\end{array}$ & $2.0035 / 2.0034$ \\
\hline \multicolumn{7}{|c|}{ humic acids of fen peat, decomposition degree $25-35 \%$} \\
\hline $\mathrm{HA}(1 \mathrm{Pl}) / \mathrm{HA}\left(1 \mathrm{Pl}_{250}\right)$ & $\begin{array}{c}0.95 / \\
0.81\end{array}$ & $\begin{array}{l}0.41 / \\
0.37\end{array}$ & $\begin{array}{l}4.22 / \\
4.91\end{array}$ & $\begin{array}{l}1.17 / \\
1.84\end{array}$ & $\begin{array}{l}2.18 / \\
2.89\end{array}$ & $2.0033 / 2.0035$ \\
\hline $\mathrm{HA}(2 \mathrm{Pl}) / \mathrm{HA}\left(2 \mathrm{Pl}_{250}\right)$ & $\begin{array}{c}0.97 / \\
0.86\end{array}$ & $\begin{array}{l}0.37 / \\
0.33\end{array}$ & $\begin{array}{l}4.14 / \\
4.67\end{array}$ & $\begin{array}{l}1.11 / \\
1.59\end{array}$ & $\begin{array}{l}1.41 / \\
1.53\end{array}$ & $2.0039 / 2.0034$ \\
\hline $\mathrm{HA}(3 \mathrm{Pl}) / \mathrm{HA}\left(3 \mathrm{Pl}_{250}\right)$ & $\begin{array}{c}0.91 / \\
0.89\end{array}$ & $\begin{array}{c}0.38 / \\
0.33\end{array}$ & $\begin{array}{c}4.38 / \\
4.50\end{array}$ & $\begin{array}{l}1.31 / \\
1.43\end{array}$ & $\begin{array}{l}1.85 / \\
2.30\end{array}$ & $2.0035 / 2.0036$ \\
\hline
\end{tabular}

The evidence presented suggests that the values of $\mathrm{H}: \mathrm{C}$ and $\mathrm{O}: \mathrm{C}$ atomic ratios for $\mathrm{HA} / \mathrm{HA}_{250}$ (humic acids of air-dried peat/humic acids of heat treated peat) are within the range $0.91 \div 1.25 / 0.81 \div 1.14$ and $0.37 \div 0.48 / 0.33 \div 0.39$.

The alteration of $\mathrm{H}: \mathrm{C}$ and $\mathrm{O}: \mathrm{C}$ values is the evidence of change in the content of macromolecule cyclic components and oxidation degree. The obtained results show that preliminary peat heat treatment decreases the values of $\mathrm{H}: \mathrm{C}$ and $\mathrm{O}: \mathrm{C}$ atomic ratios for $\mathrm{HA} / \mathrm{HA}_{250}$. This fact indicates that the content of cyclic components can increase in macromolecule. Moreover, it presents the evidence of higher modification degree of modified $\mathrm{HA}_{250}$ initial substance compared with $\mathrm{HA}$ samples. This is proved by the parameters which were obtained using the Van-Krevelen's equation: higher values of $\mathrm{A}, \mathrm{B}$ were obtained for $\mathrm{HA}_{250}$ samples compared with HA.

The impact of peat decomposition degree $(\mathrm{R})$ on the calculated atomic relations and the Van-Krevelen's equation parameters is defined: $\mathrm{R}$ growth leads to the decrease in $\mathrm{H}: \mathrm{C}$ and $\mathrm{O}: \mathrm{C}$ atomic ratios and increase in aromaticity index and the number of aromatic rings of the statistical carbon nucleus of $\mathrm{HA}$ and $\mathrm{HA}_{250}$ macromolecule. 
The atomic ratios $\mathrm{H}: \mathrm{C}$ and the value of the Van-Krevelen's equation parameters reveal the difference between peripheral and nucleus parts of $\mathrm{HA}$ and $\mathrm{HA}_{250}$ macromolecules. At the same time, it should be noted that modified HAs demonstrate aromaticity increase under the action of preliminary heat treatment which stipulates chemical transformations in peat when it is heated up to $250{ }^{\circ} \mathrm{C}$ : 1) organic matter decomposition and emission of gaseous products $\left(\mathrm{CO}, \mathrm{CO}_{2}, \mathrm{H}_{2} \mathrm{O}\right)$ during thermal decomposition; 2) interaction between peat group components and/or their residues in gaseous decomposition environment; 3 ) synthesis of new HAs [3, 6, 10-12].

The above is proved by the data obtained using EPR-spectrometer. The data show that peat heat treatment increases EPR signal for $\mathrm{HA}_{250}$ samples. The concentration of paramagnetic centers also increases: $\mathrm{I} \cdot 10^{17}=0.90 \div 2.18(\mathrm{HA})$ and $\mathrm{I} \cdot 10^{17}=1.53 \div 3.57$ $\left(\mathrm{HA}_{250}\right)$. According to [14], such results can be explained by the increase in the degree of aromatic polyconjugation of HA initial matter due to formation of new additional systems of polyconjugation caused by condensation reactions. This fact is in accord with carbon content in $\mathrm{HA}_{250}$ elemental composition and increasing number of active acidic $\mathrm{COOH}$ groups, which, in its turn, contributes to forming additional paramagnetic centers (presence of hydrogen bonds formed by functional groups) and growing the Van-Krevelen's equation parameters.

The peat heat treatment does not lead to significant change in g-factor. For all examined $\mathrm{HA}$ and $\mathrm{HA}_{250}$ samples, g-factor ranges within $2.0030 \div 2.0039$ and approximates the value of unbound electron g-factor (2.0023).

\section{Conclusion}

1. Heat treatment of different-type peat increases the carbon content and de-creases the content of hydrogen and oxygen in the elemental composition of HAs.

2. The more peat decomposition degree is, the more indifferent peat is to relative alteration of element content $\mathrm{C}, \mathrm{H}, \mathrm{O} \mathrm{N}$ in organic part of modified HA macromolecule.

3. The absorption bands typical for HAs are preserved in IR-spectra of modified HAs.

4. As the result of peat heat treatment, IR-spectra of modified HA demonstrate the decrease in the intensity of $\mathrm{OH}$-groups and C-H-groups stretch at $3400 \mathrm{~cm}^{-1}$ and $2920 \mathrm{~cm}^{-1}$ and increase in the intensity of absorption bands of $\mathrm{C}=\mathrm{O}$-groups at $1725-1700 \mathrm{~cm}^{-1}$ and $\mathrm{C}-$ O-groups of acids and phenols at $1250-1200 \mathrm{~cm}^{-1}$. This is the evidence of dehydration reaction and further interaction of pyrogenic water with the products of peat thermal decomposition accompanied by the formation of new carboxyl groups.

5. Peat heat treatment increases aromaticity and condensity of HA macro-molecule nucleus part.

6. Peat heat treatment also contributes to the concentration of paramagnetic centers.

Thus, it can be stated that preliminary peat heat treatment affects the alteration of HA composition and increases the stable nucleus part of HA macromolecule. The preceding observations lead to the conclusion that peat thermal modification has a positive impact on HAs, as it allows eliminating peripheral structures and obtaining new properties.

\section{References}

1. I. I. Lishtvan Fiziko-khimicheskaya mekhanika guminovykh veshchestv (Nauka $i$ tekhnika,1976) [in Russian]

2. N.V. Chukhareva, A.G. Zarubin, O.L. Bulgakova The Use of Principle Component Analysis in Type Classification of Air-dry Peat. IOP Conf. Ser.: Earth Environ. Sci. 21, $1-5(2014)$ 
3. N.V. Chukhareva, T. V. Korotchenko, D.S. Rozhkova Impact of Heat Treatment on the Structure and Properties of Tomsk Region Peat. Procedia Chemistry, 10, 535-540 (2014)

4. I. I. Lishtvan, N.T. Korol' Osnovnye svoystva torfa i metody ikh opredeleniya (Nauka i tekhnika, 1975) [in Russian]

5. V. P. Fadeeva Elemental Analysis of Organic Compounds with the Use of Automated CHNS Analyzers Journal of analytical chemistry 63 (11) 1094-1106 (2008)

6. N.V. Chukhareva, V. D. Tikhova, O. N. Zarubina, L. V. Shishmina The change of the peat element composition and optical properties under the thermal modification influence, the Bulletin of KrasGAU 11 85-92 (2013)

7. P. Hofer, P. Carl Patent number US 7586305 B2. Method for determining the absolute number of electron spins in a sample of extended size (2009)

8. D.S. Orlov, L. A. Grishina Praktikum po khimii gumusa (MSU, 1981)

9. I. V. Perminova Analysis, classification, and prospect of humic acids properties (2000)

10. N.V. Chukhareva Issledovanie kinetiki termicheski aktivirovannykh iz-meneniy sostava i svoystv torfyanykh guminovykh kislot: extended abstract of Cand. Sci. (Chemistry) Dissertation (2003) [in Russian]

11. L. I. Tarnovskaya Zakonomernosti izmeneniya gruppovogo sostava torfa $\mathrm{v}$ protsesse termoliza: extended abstract of Cand. Sci. (Eng.) Dissertation (1985) [in Russian]

12. D. A. Bazhenov Modelirovanie fiziko-khimicheskikh zakonomernostey nizkotemperaturnogo razlozheniya torfa: extended abstract of Cand. Sci. (Chemistry) Dissertation (2000)

13. D.V. Van Krevelen Nauka ob ugle (GNT, 1960) [in Russian]

14. S. N. Chukov Paramagnitnaya aktivnost' pochvennogo gumusa i ee iz-menenie pri antropogennom vozdeystvii (na primere serykh lesnykh pochv): extended abstract of Cand. Sci. (Biology) Dissertation (2006) [in Russian] 